Article

\title{
Accurate Reconstruction of the Roman Circus in Milan by Georeferencing Heterogeneous Data Sources with GIS
}

\author{
Gabriele Guidi * (D), Sara Gonizzi Barsanti (), Laura Loredana Micoli and Umair Shafqat Malik \\ Department of Mechanical Engineering, Politecnico di Milano, 20156 Milan, Italy; \\ sara.gonizzi@polimi.it (S.G.B.); laura.micoli@polimi.it (L.L.M.); umairshafqat.malik@polimi.it (U.S.M.) \\ * Correspondence: gabriele.guidi@polimi.it; Tel.: +39-02-2399-7183
}

Received: 11 August 2017; Accepted: 14 September 2017; Published: 20 September 2017

\begin{abstract}
This paper presents the methodological approach and the actual workflow for creating the 3D digital reconstruction in time of the ancient Roman Circus of Milan, which is presently covered completely by the urban fabric of the modern city. The diachronic reconstruction is based on a proper mix of quantitative data originated by current 3D surveys and historical sources, such as ancient maps, drawings, archaeological reports, restrictions decrees, and old photographs. When possible, such heterogeneous sources have been georeferenced and stored in a GIS system. In this way the sources have been analyzed in depth, allowing the deduction of geometrical information not explicitly revealed by the material available. A reliable reconstruction of the area in different historical periods has been therefore hypothesized. This research has been carried on in the framework of the project Cultural Heritage Through Time-CHT2, funded by the Joint Programming Initiative on Cultural Heritage (JPI-CH), supported by the Italian Ministry for Cultural Heritage (MiBACT), the Italian Ministry for University and Research (MIUR), and the European Commission.
\end{abstract}

Keywords: digital heritage; knowledge representation; 3D survey; data integration; GIS; $4 \mathrm{D}$ reconstruction

\section{Introduction}

The 3D digital representations through time of cultural heritage sites can be useful in order to study and preserve their memory, to properly communicate them to the public even when bad conservation conditions occur, and to plan their maintenance and promotion.

Usually, 3D modeling involved in the study of Cultural Heritage includes two definitively distinct categories: reality-based and reconstructive [1].

Reality-based 3D models are generally intended, as those obtained with high accuracy thanks to both active and passive 3D acquisition technologies, are nowadays largely available, such as laser scanners or Structure from Motion (SfM)/Image Matching (IM) photogrammetry, that allow one to sample the exterior surfaces of the object, building, site, or landscape of interest at high resolution. The dense 3D cloud provided is then meshed and possibly texturized, originating what is usually indicated as a reality-based 3D model [2,3].

On the other hand, reconstructive 3D models are those originated by a much less dense set of geometrical information, due to the fact that they are referred to objects, buildings, sites, or landscapes not existing anymore in their original form [4,5].

Paul Reilly introduced the concept of Virtual Archaeology in the early 1990s [6], pointing out how reconstructive models play a crucial role in archaeological studies for the possibility to visualize interactively non-existing architecture [7]. It is a tool for the shared synthesis of knowledge, for interactive interpretation of archaeological ruins, and for cultural dissemination [8]. In addition, 
virtual reconstruction in archaeology has been introduced as a novel method for finding archeological discoveries [9].

However, differently from reality-based models, a virtual reconstruction is necessarily based on a set of assumptions, and the acceptance of a certain level of uncertainty [10] that can be limited by integrating historical sources, providing, even in an indirect way, additional geometrical constraints [11]. In order to define shared methodologies for approaching the problem of 3D reconstruction of partially or totally non-existing archaeological structures, in the past two decades, different relevant initiatives have been taken including the Virtual Archaeology Special Interest Group (VASIG) of the international organization "Computer Applications and Quantitative Methods in Archaeology" (CAA), the Cultural Virtual Reality Organization (CVRO), and the European project EPOCH (www.epoch-net.org). These and other contributions have laid the foundation of the "London Charter", whose main aim is to establish internationally-recognized principles for the use of computer-based visualization of cultural heritage [12].

Different projects have faced the issues of virtual reconstruction in archaeology e.g., aiming at the digital reconstruction of large cities [13], the digital reunification of an ancient structure on site with decoration conserved in a different location [14], the construction of knowledge models behind the studied site [15], the different interaction typology between user and digital contents [16], and the public engagement and the dissemination of archaeological data [17].

Technically, the reconstruction activities might be oriented more to the study of a structure using engineering tools [18,19], to the accurate visualization of the reconstructed scene $[20,21]$, or to the exploration of a particular site through time [22].

Even if a reconstruction can simply be based on drawings originated by previous studies, several works appeared in the literature [23-26] which have shown that a serious reconstruction work should start from the accurate digitization of the existing remains, enriched with additional pieces of information provided by various non-uniform sources.

However, there are cases where the three-dimensional diachronic reconstruction is particularly complex. There are several reasons for this: (i) the nearly total absence of remains to be surveyed; (ii) one or more time periods of an artefact's life with little historical documentation; (iii) uncertainty of sources; (iv) difficulty to correlate documents and data to a three-dimensional representation.

This paper presents an experimental activity defined by the project Cultural Heritage Through Time-CHT2 (http:/ / cht2-project.eu), funded in the framework of the Joint Programming Initiative on Cultural Heritage (JPI-CH) supported by the Italian Ministry for Cultural Heritage (MiBACT), the Italian Ministry for University and Research (MIUR), and the European Commission. Its goal is to develop time-varying 3D products, from landscape to architectural scale, to envisage and analyze lost scenarios, or visualize changes due to anthropic activities or intervention, pollution, wars, earthquakes, or other natural hazards. The main aim of the CHT2 project is to merge heterogeneous information and expertise to deliver enhanced four-dimensional (4D) digital products of heritage sites. CHT2 is working on the full integration of the temporal dimension, its management and visualization, for studying and analyzing Cultural Heritage structures and landscapes through time. The proposed methodology for the whole project described in [27], suggests different ways to reconstruct the diachronic life of an historical object, monument, or landscape.

Regarding the case presented in this paper, given the limited detectable findings, the work began with an in-depth philological analysis from the collection of historical and archival data, integrating the various contributions in the area, beginning in early 1939 [28-31].

The case study covers the south-west area of the city center of Milan that corresponds to the Roman Circus area, where it is possible to see several traces of different historical periods from ancient times, to the densely urbanized structure of the present days. According to some archaeological findings, Milan was inhabited since the 5th century BC in the area corresponding to the current Via Meravigli, Via Valpetrosa, and the Piazza del Duomo. In this area, some protohistoric tracks converge, with traces of the later Roman roads, are still recognizable in the city plan. Such roads 
connected Milan with some towns and villages to the northwest neighborhoods belonging initially to the Golasecca culture, a prehistoric civilization located in the Ticino River area from the Bronze Age until the 1st century BC.

In the 2nd and 1st centuries BC, excavation and leveling took place, in order to adapt the ground to the Roman urban model. At that time, the first urban planning was put in place, probably maintaining the Golasecca road network. The entire settlement occupied an area of 80 hectares, with a spatial organization influenced by differences in height, watercourses and by the existing routes. In the second half of the 1st century BC, the Romanization of the territory was completed [31,32]. In the first Roman city plan, the investigated area, now occupied by the Archaeological Museum, was first dedicated to housing and production activities. These activities were probably related to metal extraction from the sediments of the Nirone River and the related processing. This hypothesis has been confirmed by recent excavations, which revealed the presence of a pre-imperial domus. At the end of the 1st century $\mathrm{BC}$, good quality residences and production activities would have been present. A subsequent domus, built in the 1st and 2nd centuries AD, was later transformed into a prestigious domus in the 3rd century AD. For none of these buildings, unfortunately, is a complete plan known [33].

In the year $286 \mathrm{AD}$, Milan became the capital of the Western Roman Empire, under the emperor Maximian. During the imperial period, up to 402 AD, the area was modified by the construction of major buildings, such as the imperial palace, the circus, and the defensive walls [29,34].

The Circus was the open-air venue for chariot and horseraces; or rather, the place dedicated to the celebration of the Emperor's greatness. For this reason, circuses were generally located near the Imperial Palace [35].

Milan's circus was also adjacent to the defensive walls, with which it shared the western part. This particular location probably resulted in a number of peculiarities, such as the absence of a Triumphal Arch on the apex of the curve. Although the circus of Milan was one of the most important in the late Roman empire, only a few traces are still available: a tower of the city walls, a tower of the carceres reused as a bell tower (formerly belonging to the Monastero Maggiore), and some sections of the walls or foundations in private properties nearby $[30,35,36]$. Historical sources report the existence of the circus until the Lombard era. From that period, as happened to other monuments in Milan, the materials of the Roman structures were reused in new construction projects.

Archaeological studies were conducted mostly at the beginning of the 1900s and after World War II, during the reconstruction of some private and public buildings, when it was possible to see the archaeological remains. Unfortunately, nowadays, only small portions of the monument remain visible; moreover, much of the historical documentation was lost in a fire during World War II. Starting from the 1960s, the area was used as the headquarters of the Archaeological Museum of the Municipality of Milan (Civico Museo Archeologico di Milano), that still takes care to preserve the memory of the various eras represented in this part of the town. The rest of the area occupied by the ancient Roman circus is instead almost entirely occupied by residential buildings [37]. This area also includes the Church of San Maurizio, whose nucleus is of early Christian origin, and which was built in the form we know today at the beginning of the 1500s. Small remains of the circus are still visible in the basements of modern buildings in that area. Many questions are still open about the structure of the building and its relation to the surrounding area, including the imperial palace and the town fortification walls.

\section{Materials and Methods}

In some cases [26,38], diachronic reconstruction of a monumental complex started with the three-dimensional survey of the actual state of the monument, and an investigation of the traces of different phases of the building, along with suitable philological research. In the case of the Roman circus of Milan, given the limited detectable findings, the work started with an in-depth philological research campaign, beginning with historical and archival data. All kinds of sources (texts, maps, drawings, archaeological reports and restriction decrees, photographs) have been integrated to hypothesize a reconstruction of the monument, by referencing such documents to that specific location of the city. 
The research began with the bibliography related to the study of the monument. This was useful for gathering all the information available about the previous research and the excavations done during the past centuries.

Especially important for the study of the monument was the book of De Capitani D'Arzago [28], an archaeologist who thoroughly studied the Roman circus of Milan in the late 1930s. His studies confirmed the existence, location, and essential size of the circus, thanks to the discovery of the parallel walls, some portions of the foundations, and a large part of the curve.

Another important book is that of Humphrey [35], in which many Roman circuses, among them also the circus of Milan, were investigated. Thanks to this information, it was possible to interpret the missing parts of the monument by comparing its shape to others from the same period. This research is fundamental when analyzing and reconstructing an ancient building that is no longer visible.

Another step of the work was the collection of maps, drawings and images concerning the various topics covered in the research (Figure 1). Drawings and historical paintings are fundamental for gathering information no longer available today. This kind of approach was useful for gathering typological indications and validating the reconstructive hypotheses proposed by scholars. In our case, we have found sources regarding: (i) the domus of the pre-imperial era; (ii) Roman circuses built in the Empire in the same period; and (iii) monasteries of the Benedictine order.

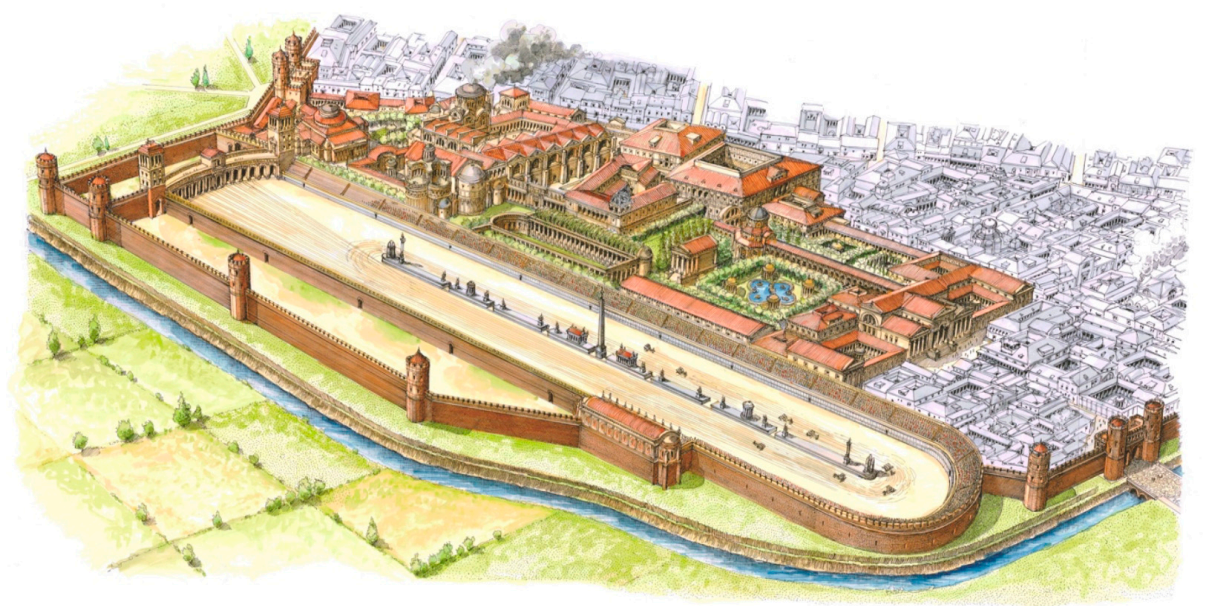

(a)

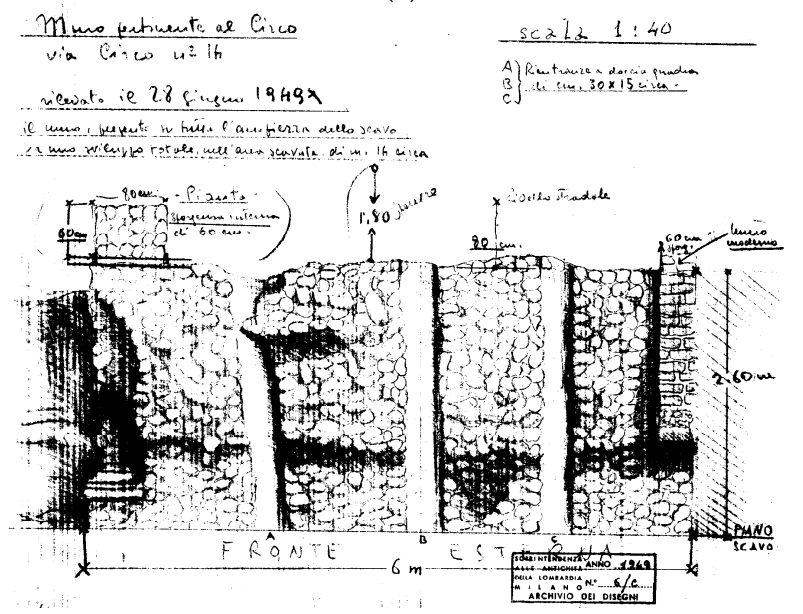

(b)

Figure 1. Different types of archival data: (a) reconstructive drawing of the Circus and the Imperial Palace (F. Corni, courtesy of Civico Museo Archeologico di Milano); (b) drawing of an archaeological excavation carried out at Via Circo 14 in 1949 (courtesy of Ministero dei beni e delle attività culturali e del turismo). 
Unfortunately, in the case of Milan, only modest graphic representations of the involved monuments were available, with reference to their active period. As far as more recent times are concerned, all the drawings of survey campaigns carried out in the area have been collected. Since many buildings destroyed by bombing during World War II (WW2) were rebuilt, in the post war period, the excavations for the foundations of the modern buildings, in some cases, revealed archaeological finds that sometimes were used as the basement for the new building. In other instances, for example, in correspondence to new roads or other unbuilt areas, such findings were simply covered. Sometimes, notes and sketches made during previous excavations revealed crucial pieces of information for defining the structure of the monument.

Next, a thorough iconographic research campaign was carried out, collecting different maps from various periods that could highlight the urban structure of the area. About 60 city maps representing different historical periods from the Renaissance to the present day have been identified at the "Civica Raccolta delle Stampe Achille Bertarelli" in Milan and analyzed to study the evolution of the urban area. Another type of data taken into account were the photographs taken mainly during the post-WW2 excavations, as for example, those shown in Figure 2. Images of artefacts and structures inside the urban area, taken from different points of view and sometimes referred to two or more different periods of their existence, are a valuable support for the three-dimensional reconstruction process.

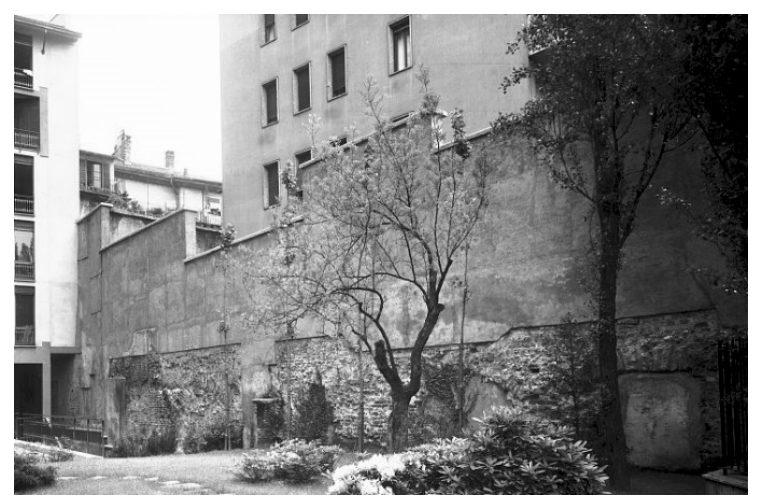

(a)

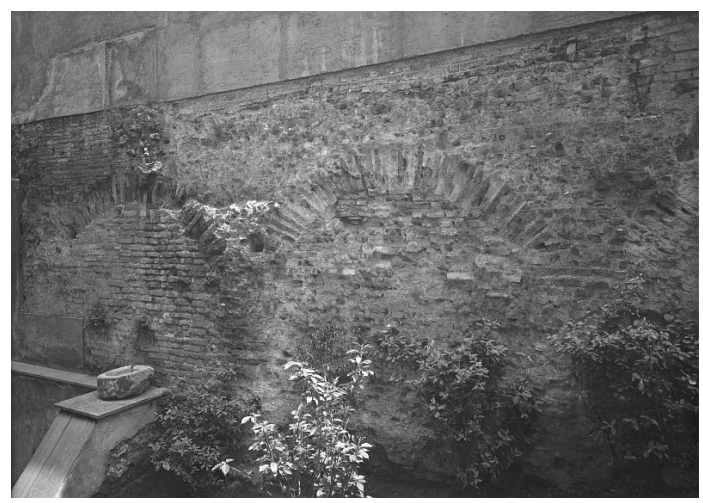

(b)

Figure 2. Photographs of the remains of the external wall of the circus visible in a private garden of a building in via Vigna 1: (a) the entire portion of the remains; (b) a detail of the arches sustaining the podium visible on the wall (courtesy of Ministero dei beni e delle attività culturali e del turismo).

In addition, a research campaign in the photographic archive at the Superintendence office was made regarding to the area of interest. About one thousand images were found, and about 100 of them were selected for use in this project. The selection regards artefacts visible during construction projects (e.g., the metro, new skyscrapers) or inspections of the Superintendence office. These images are a valuable documentary heritage because many artefacts, embedded in the foundations of modern buildings, are no longer visible.

The next step of the research, propaedeutic to the $4 \mathrm{D}$ reconstruction, involved the identification and survey of all the visible portions of the monument.

Starting from a detailed map of the circus made in the late 1930s, the accurate positioning of all the remains of the circus and its connected structures was checked.

This part of the work dealt also with a capillary search, in connection with the inspectors of the Superintendence of Milan, of all the street numbers of the actual buildings where the remains are still visible in the basements. During this search, it was observed that all the private houses of interest, due to archaeological findings, are under restrictions, but given the period in which these restrictions were defined, most of them are brief and unclear. Hence, it was difficult to identify the individual structures, with regards to their location and their extent, as this required huge archival work. 
All areas subjected to archaeological restrictions have been screened along with the Superintendence office, in order to assess the actual presence of remains, their state of conservation and the opportunity to do a three-dimensional survey.

The 3D survey of all the selected remains is a crucial stage for generating a reliable starting point for the reconstruction. Depending on the conditions of operation, such 3D digitization is being made with both SFM photogrammetry and laser scanning, depending on the available conditions of lighting, working space, etc. The monument portions that are detected and suitably georeferenced are used to validate the archaeological excavations of the past, and to give the main constraints over which the three-dimensional reconstruction have been progressively generated.

In addition to the validation of historical plans, the three-dimensional portions are fundamental as elements of proportion, in relation to the examples of the same type of monument highlighted by other sources, to define the elevation of the building, typically, the most critical parameter in the reconstruction of any ancient building not existing anymore. The survey work started first on an unrestricted area belonging to the Archaeological Museum of Milan, which was a supporting partner in the CHT2 project. The first two components of the circus that have been digitized are: (i) the so-called "square tower", originally belonging to the carceres of the circus, and nowadays used as the bell tower of the church dedicated to San Maurizio; and (ii) the so-called "polygonal tower", part of the defensive walls of the city. The two buildings were surveyed both with laser scanning, using a Faro Focus 3D scanner, and with photogrammetry, using a Panasonic DMC GH4 with a $12 \mathrm{~mm}$ lens and a Canon 5D MkII with a 20 mm F 2.8 lens. The resulting digital models are shown in Figure 3.

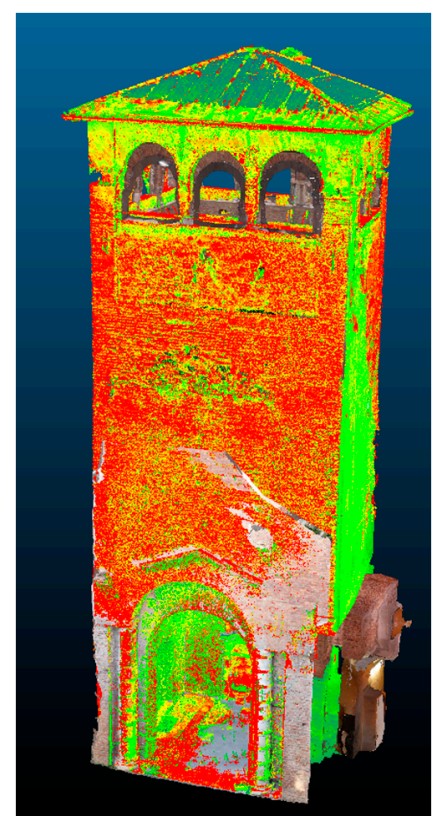

(a)

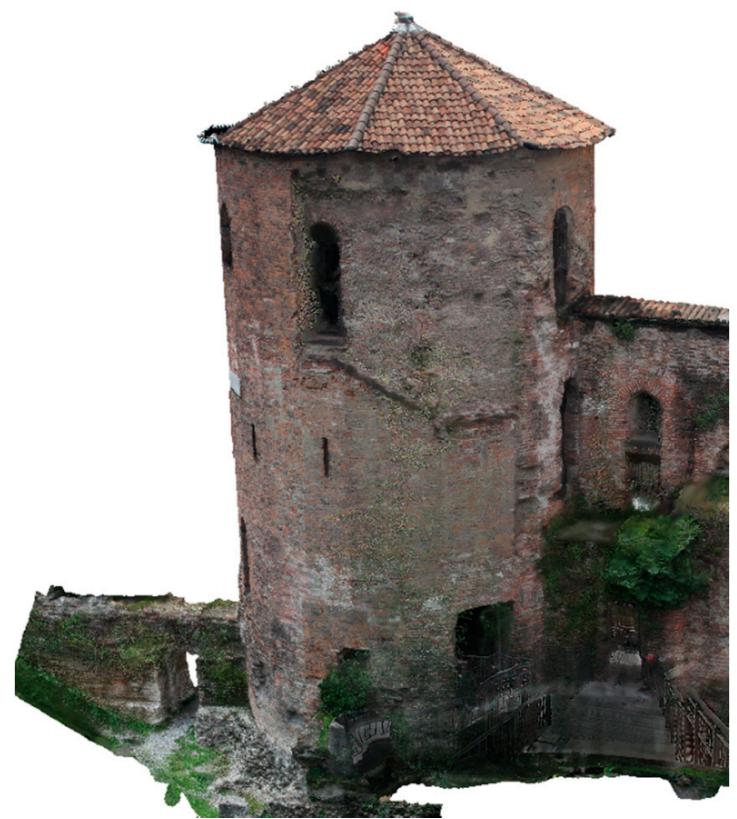

(b)

Figure 3. 3D models of structures still standing in the area: (a) square tower, belonging to the carceres of the circus. The model was created by the integration of photogrammetry for the interiors and laser scanning for the exteriors; (b) polygonal tower, which was part of the late roman city walls. In this case the model was originated exclusively by photogrammetric data.

Another useful contribution to our study comes from a significant part of the outer circus wall, nowadays belonging to the garden of a private condominium in Milan, via Vigna 1 (Figures 2, 4 and 5), and a smaller remnant of the inner wall, also called the podium wall. It corresponds on one side to the limit of the circus racetrack, and on the other side to the lower limit of the cavea. This latter portion of the foundations and inner wall are inside the cellar of the above-mentioned condominium. 
The external wall was surveyed using both photogrammetry, with a NEX 6 camera coupled with a $24 \mathrm{~mm}$ F 1.8 Zeiss lens and laser scanning, using a Faro Focus 3D 120 device. The small portion of the podium wall was surveyed with the Faro laser scanner only, connecting the inside to the outside through a set of redundant scans taken from several positions along the path from the cellars to the exterior garden. The last survey performed relates to a portion of a wall inside the basement of a building in via Luini. It refers to a western portion of the external wall of the circus. What is visible today is a $2-3 \mathrm{~m}$ long foundation, cut by a modern wall. The survey was performed using a Faro Focus 3D 120 device.

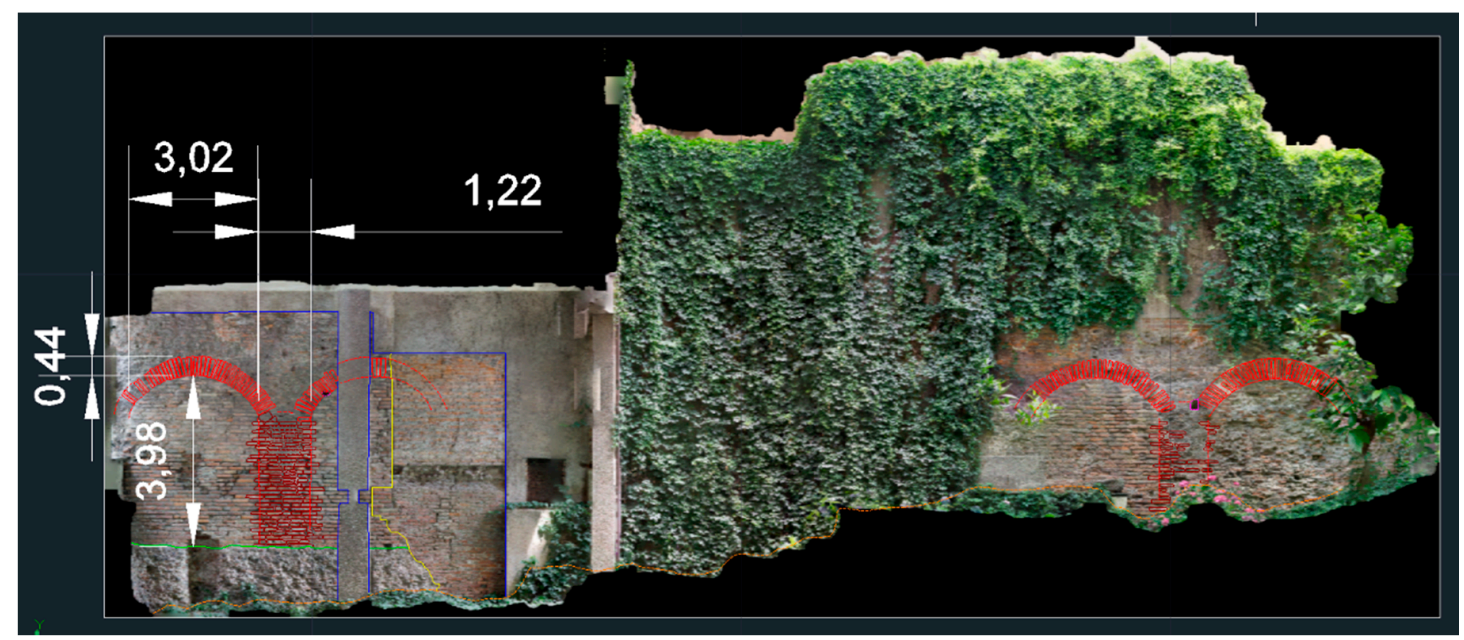

Figure 4. Documentation of the main portion of the circus outer wall still standing through an orthoimage, providing the measurement of the arches supporting the audience seats.

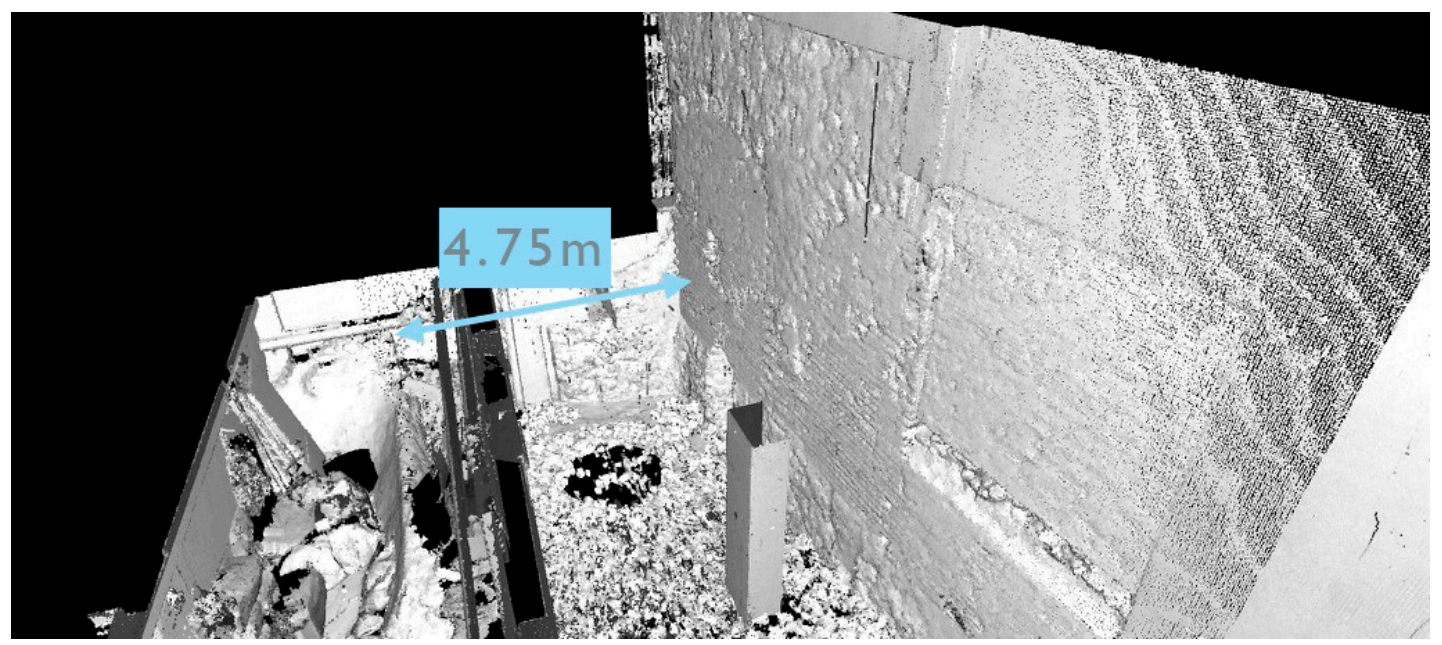

Figure 5. Documentation of the main portion of the circus outer wall still standing: laser scan including a small remnant of the inner wall found in a private basement, providing the height of the wall in this point of the structure, and its distance from the inner one.

\section{Results}

These surveys in via Vigna 1 were important for measuring several crucial geometric elements, needed for the 3D reconstruction: (i) the height of the remains of the outer wall of the circus in this area, corresponding to $7 \mathrm{~m}$. Several sources, however, stated that this is not the whole height of the circus.

This was confirmed by other measurements, taken at the curved end of the circus on the side opposite to the carceres, that reached $8.40 \mathrm{~m}$; (ii) the height of the traces of the arches, visible on the 
inner side of the exterior wall, that identify the starting point of the vaults, located at $3.98+0.44=$ $4.42 \mathrm{~m}$ (Figure 4); (iii) the periodicity of the arches representing the traces of the vaults in the exterior wall, equal to $3.02+1.22=4.24 \mathrm{~m}$ (Figure 4); and (iv) the precise distance between the inner and the outer wall $(4.75 \mathrm{~m})$ shown in Figure 5.

This latter information, together with the incline of the seating tiers, which according the bibliographic sources in other circuses of the same period is around $45^{\circ}$ [35], allowed us to calculate the positioning of the tiered seats with maximum likelihood, as shown in Figure 6.

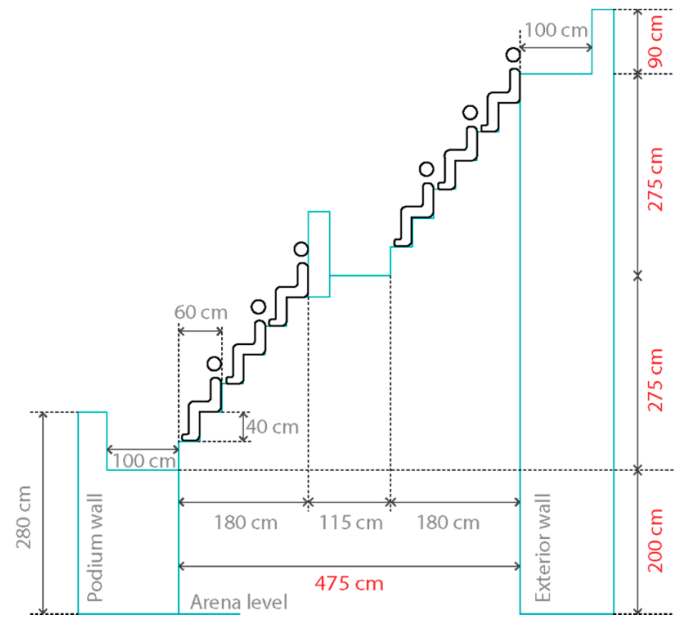

(a)

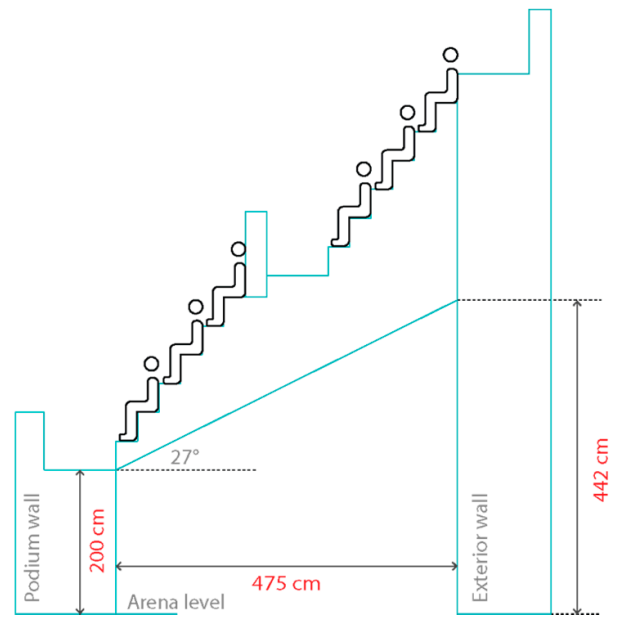

(b)

Figure 6. Hypothetical cross-section of the circus showing the distribution of seats, according to the measurements coming out from the laser scanning campaign (in red are the measurements taken on the field): (a) subdivision between different social classes (b) Hypothetical inclination of the vault.

As already suggested in the literature [29], the typical subdivision of the crowd into social classes would lead to the hypothesis of two orders of three seats, with $30 \mathrm{~cm}$ for seating and 30 for the feet, as shown in Figure 6a. This would give six rows of seats divided in two orders, separated by a space, with the double function of a walking lane for reaching the seats, and for separation between the nobles, typically placed closer to the racetrack, and those of the plebeians, in the upper zone.

An element that might seem peculiar in this reconstruction is the positioning of each seat on a plane different from that of the feet, which would be more economical. However, the arrangement shown in Figure 6a was typical of late Roman circuses, like the Circus of Maxentius in Rome, belonging to the same period. In addition, the latter seat organization would give a smaller inclination of the seats zone. Actually, a single large area of $60 \mathrm{~cm}$ for the seat of the lower person and for the feet of the upper person would lead to an increase in height of $40 \mathrm{~cm}$, corresponding to the minimum height for a seat with respect to the floor level. This would give an angle of $37^{\circ}$, not compliant with the various considerations in the literature and to the global height of the outer wall. Contrarily, the seat organization shown in Figure 6a would give a global height increase of $5.50 \mathrm{~m}$ for $4.75 \mathrm{~m}$ of distance, corresponding to an angle of $49^{\circ}$. This reconstruction also fits better with the global height of around $9 \mathrm{~m}$ for the exterior structure. The sources give a $2 \mathrm{~m}$ height of the planking level of the first (the lower) row of seats, corresponding to the height of the podium wall shown in Figure 6a. This height, plus the $5.50 \mathrm{~m}$ needed for accommodating the six rows of seats, gives a height of $7.50 \mathrm{~m}$ for the last (the upper) seating. Behind the shoulder of the upper row of seats, a small wall is expected, with a height not lower than $0.9 \mathrm{~m}$ for preventing accidental falls from the upper level of seats. This gives a total height of $8.40 \mathrm{~m}$ from the arena level that is coherent with the measurement found in another area of the circus.

A second element that could be measured refers to the structure of the arches connecting the outer wall to the podium wall. They are segmental arches $3.02 \mathrm{~m}$ wide, reaching a height of $4.42 \mathrm{~m}$ from the 
foundations, as shown in Figure 4 and represented schematically in Figure $6 \mathrm{~b}$. This structure refers to the support of the podium, thus also having a corridor function for the passage of the public.

Considering the construction techniques in use during the Roman period, and comparing the remains of the circus of Milan with other performance buildings, the most probable structure was composed of a vault forming the ceiling of the corridor, intersected by architraves sustaining the podium. This structure is still visible, for example, in the Circus Maximus and the Colosseum in Rome (Figure 7). Even if these two buildings are earlier than the Circus in Milan, they represent the best conserved examples to analyze and understand the Roman construction technique of performance buildings.

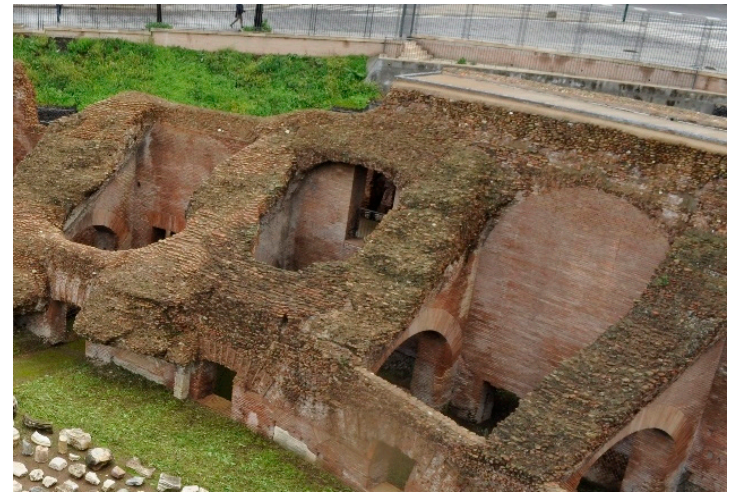

(a)

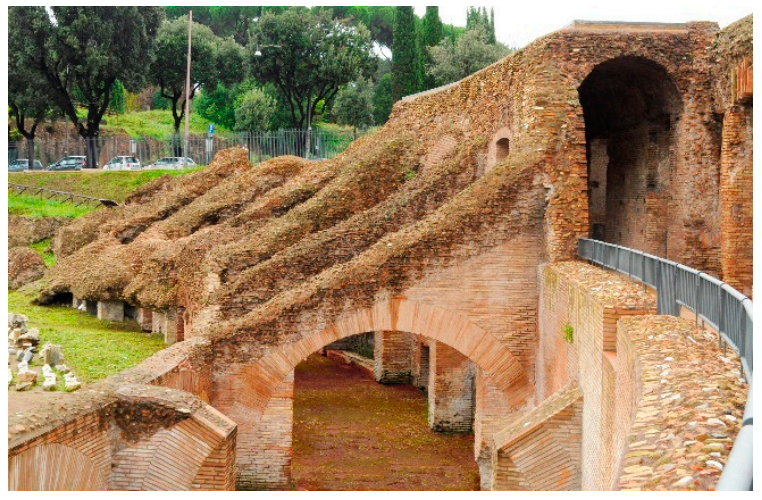

(b)

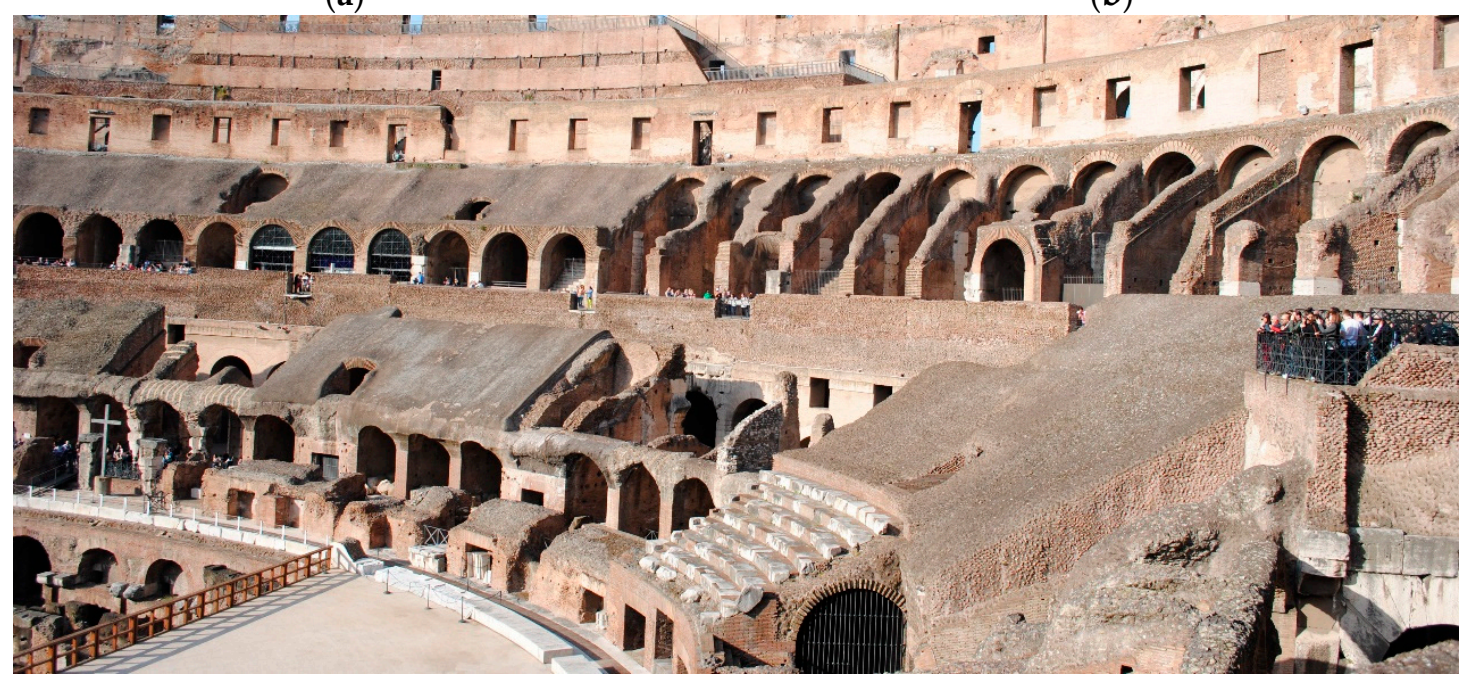

(c)

Figure 7. Examples of the structure built as a support of the podium with a double purpose, upholding the structure of the seats and corridor for the public to reach their seats: $(\mathbf{a}, \mathbf{b})$ Circus Maximus in Rome; (c) Flavius Amphitheatre (Colosseum) in Rome.

Although there is evidence of the sustaining arches and pillars on the external wall, it is not possible to identify the same structure on the ruins of the internal one, due to the insufficient height of the remains. For the following $4 \mathrm{D}$ reconstruction, the only way is to analyze comparable structures and to utilize the model.

The connection should be close to the top of it on the interior side of the podium wall for limiting the slope of the vault. This defines a lower end of the vault at $2 \mathrm{~m}$ from the foundation level, rising to $4.42 \mathrm{~m}$, corresponding to a vertical difference of $4.42-2=2.42 \mathrm{~m}$. Such displacement, on a horizontal distance of $4.75 \mathrm{~m}$, defines an angle of $27^{\circ}$ with respect to the horizontal line, as is indicated in Figure $6 \mathrm{~b}$. 


\subsection{Georeferencing and Harmonization of the Different Sources}

All the data collected are crucial for hypothesizing and reconstructing the circus. In order to have a shared basis from which to start, a commercial GIS platform was used (ArcMAP by ESRI). The first step was for georeferencing the most important survey of the past, represented by the hypothetical map of the circus made in the late 1930s [31] using the 3D technologies available at that time. Even if no precise measurement of the underground remains was made with respect to the modern city, this map, nevertheless, represents a reasonable starting point for the following reconstruction phases. The first step was, therefore, the orientation of the De Capitani map with respect to the cadastral map provided by the municipality of Milan. The drawing was georeferenced using the Helmert transformation, using as references, the profiles of some recognizable modern buildings visible also on the De Capitani map. The remains of the circus highlighted on the map were then transformed from raster to vector drawings with AutoCAD, in order to have them as curves to be used for extruding a 3D/4D reconstruction of the circus (Figure 8a).

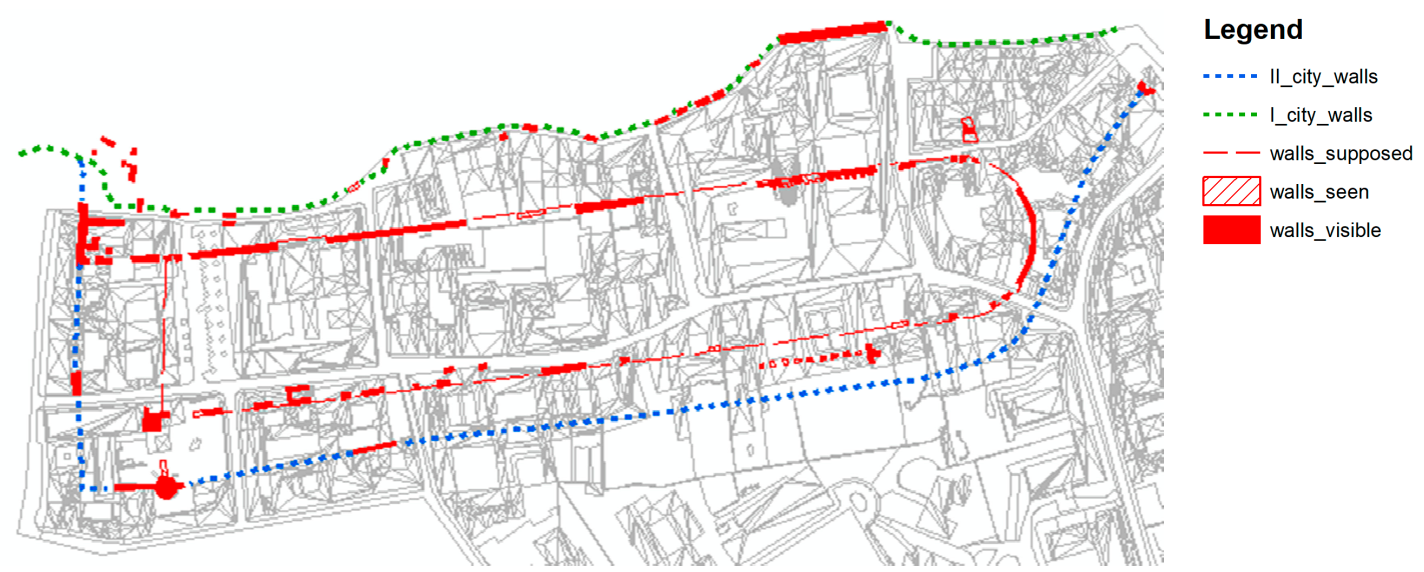

(a)

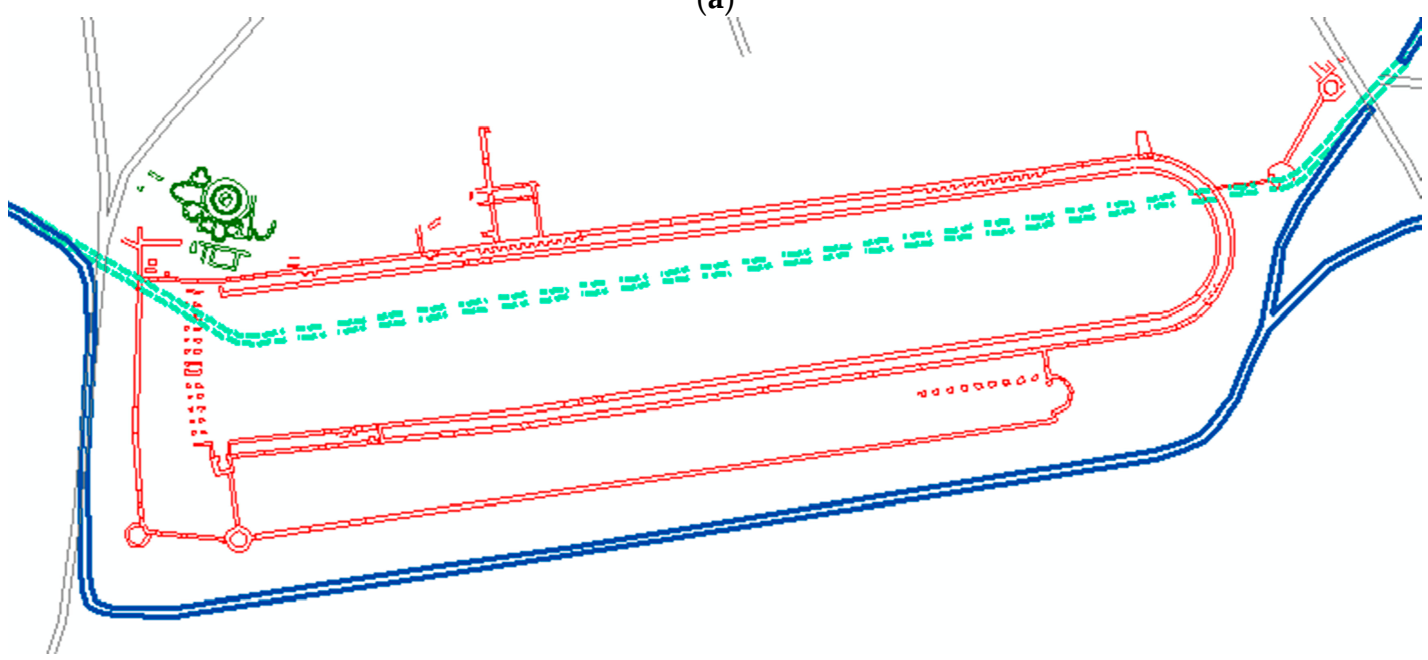

(b)

Figure 8. Georeferenced representation of the circus maps corresponding to different periods in time: (a) De Capitani's map indicating various information about the walls of the circus excavated or guessed; (b) Mirabella Roberti's update highlighting the different paths of the river, before (blue dashed line) and after the intervention (blue continuous line) for building the circus.

The map of Mirabella Roberti [29], who updated the one from De Capitani in the 1980s, was then georeferenced and drawn. Added to this was other information about the hypothesized ancient city in the reigns of the emperor Augustus and Maximian (i.e., before and after the circus construction), 
in order to underline the changes in the topography of the city after some huge interventions occurred in the historical phase before the building of the circus. The most important of these regarded the change of the course of the river Seveso that used to flow in the area where, during Maximian's rule, the circus and the new city walls were built (blue dashed line in Figure 8b).

The route of the river was diverted to make space for the construction of the circus just beside the imperial palace, and follows the itinerary of the new city walls. This is clearly highlighted in Figure $8 \mathrm{~b}$ by the different paths of the river, before (blue dashed line) and after the intervention (blue continuous line). Here, the only excavated structure is the imperial palace (colored in green in the top left corner of the figure).

The two maps of the circus were then overlapped; as is clearly evident in Figure 9, this makes some differences evident. The first one is that Mirabella Roberti's map seems more complete, with the indication of both the external and internal walls, and the indication of few structures along the Circus length, for example, the tower in correspondence with the southern part of the buildings, or the one with an apse along the western part of the Circus. The main difference, however, is the divergence in length of $10 \mathrm{~m}$ between the two maps. The De Capitani map gives a total internal length of $460 \mathrm{~m}$ while the Mirabella Roberti one gives $470 \mathrm{~m}$. This information will be confirmed or updated at the end of the surveys of all the visible and existing portions of the circus walls, but, as of now, it seems that Mirabella Roberti's map is more reliable, being drawn around 50 years after De Capitani's, and so, more complete because it includes all the most recent excavations.

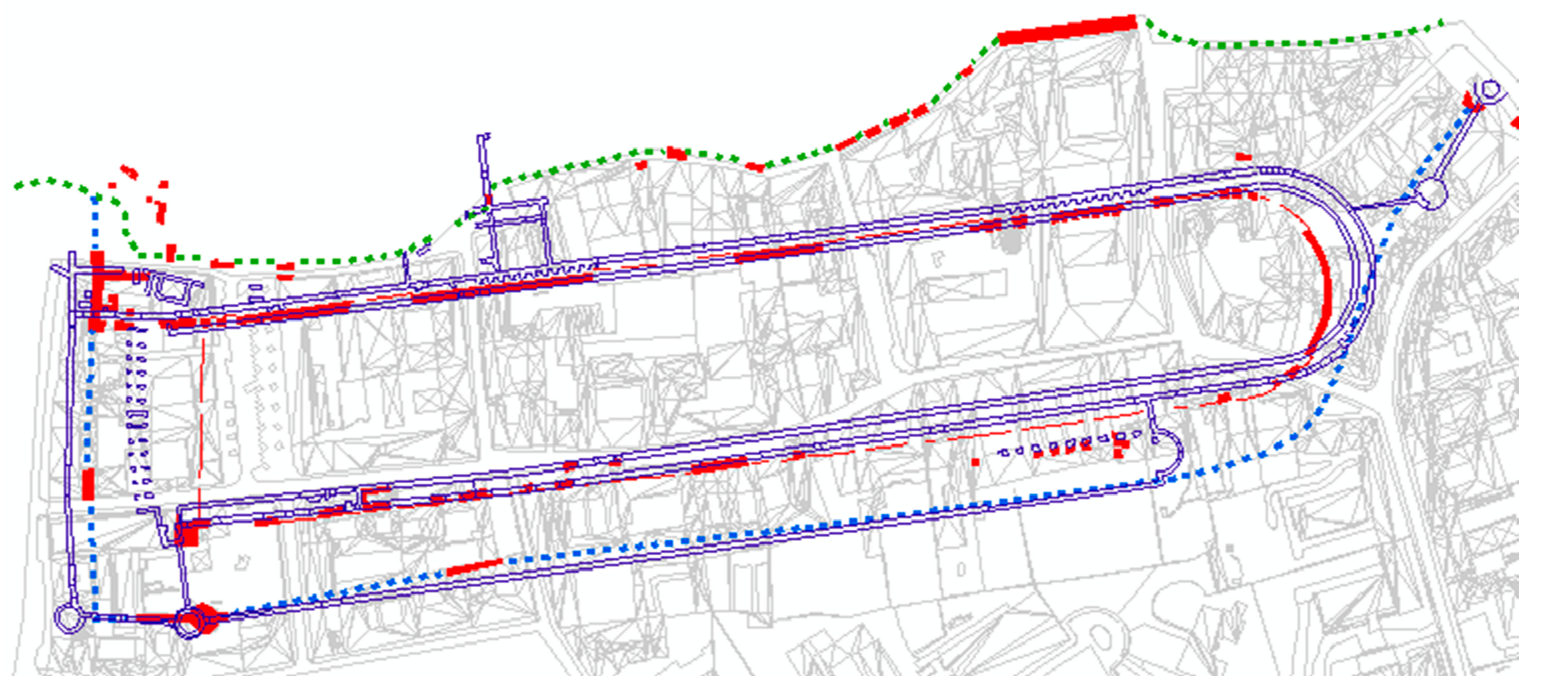

Figure 9. The overlapping of the two maps of the Roman Circus of Milan: De Capitani's map in red, and Mirabella Roberti's map in blue.

This georeferenced map was then connected to a geodatabase that includes all the information collected during the archival review (Figure 10). The fields of the tables were chosen coherently with the previously existing metadata associated with the archival documents. To each portion of wall identified, the information about excavations, documentation, restriction decrees, and images, was connected.

\section{2. $4 \mathrm{D}$ Reconstruction}

The so-called 4D reconstruction is usually intended as the process for obtaining the shape of real objects and their changes along a temporal dimension, based on a methodology for integrating the various sources of non-uniform data [27]. In addition, the surveys described above, georeferenced to the topographic network of the city, helped to identify the accurate positioning of the buildings, and to obtain precise measurements of shape and size of the structures. By merging such data related to 
the current state of the monument with the vast archival material collected, a rearrangement of the historical representations was made, including the normalization of the historical plans in a uniform scale. From such an integrated base of information, a $4 \mathrm{D}$ reconstruction is ongoing, together with the archaeologists' input, in order to better identify the proper reconstruction of the ancient building and all the changes that affected the area from the late Roman period until the present time.

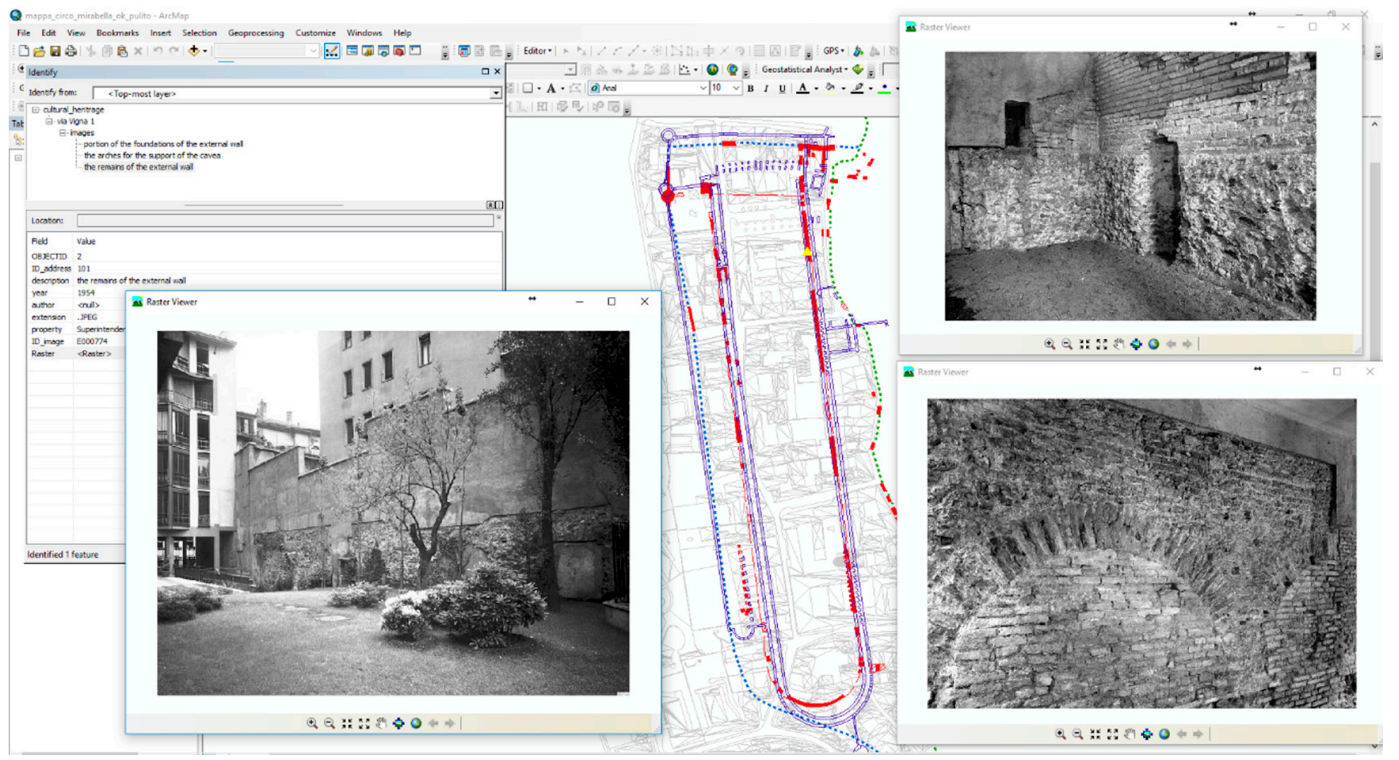

Figure 10. The creation and implementation of the geodatabase connected to all the different portions of the circus' walls identified and surveyed with the metadata related to the ruins and to the archival images collected.

The reconstruction began with the georeferenced maps of De Capitani and Mirabella, which served as a starting point for the 3D model (Figure 11), giving the total length of the monument, which will be confirmed at the end of the surveys, and the connection of all the parts that are not visible in the present time.

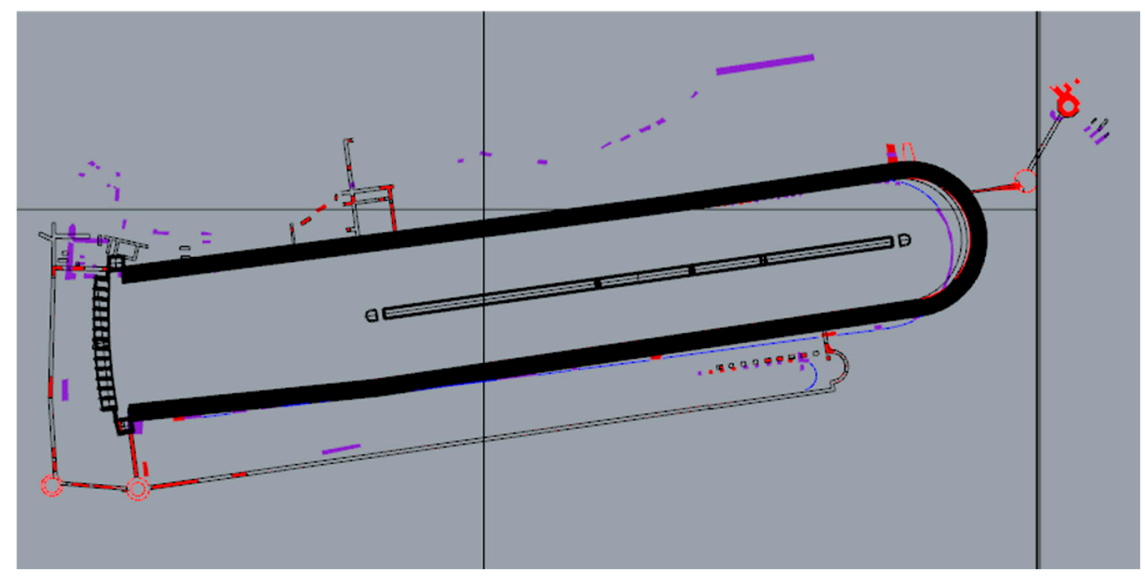

Figure 11. The reconstruction of the circus starting from the documentation provided from the past studies reported on different layers of the same GIS.

Starting with the plan, the 3D reconstruction (Figure 12a) added the information collected during the careful work in the archive of the Superintendence that related to the height of the external wall in 
different parts of the structure. From the documentation of the excavations, it was possible to know that the external wall was higher in the southern part, where it served also as city walls, while the height in the eastern part was ascertained from the traces of the wall of the circus on the square tower now in the garden of the Archaeological Museum.

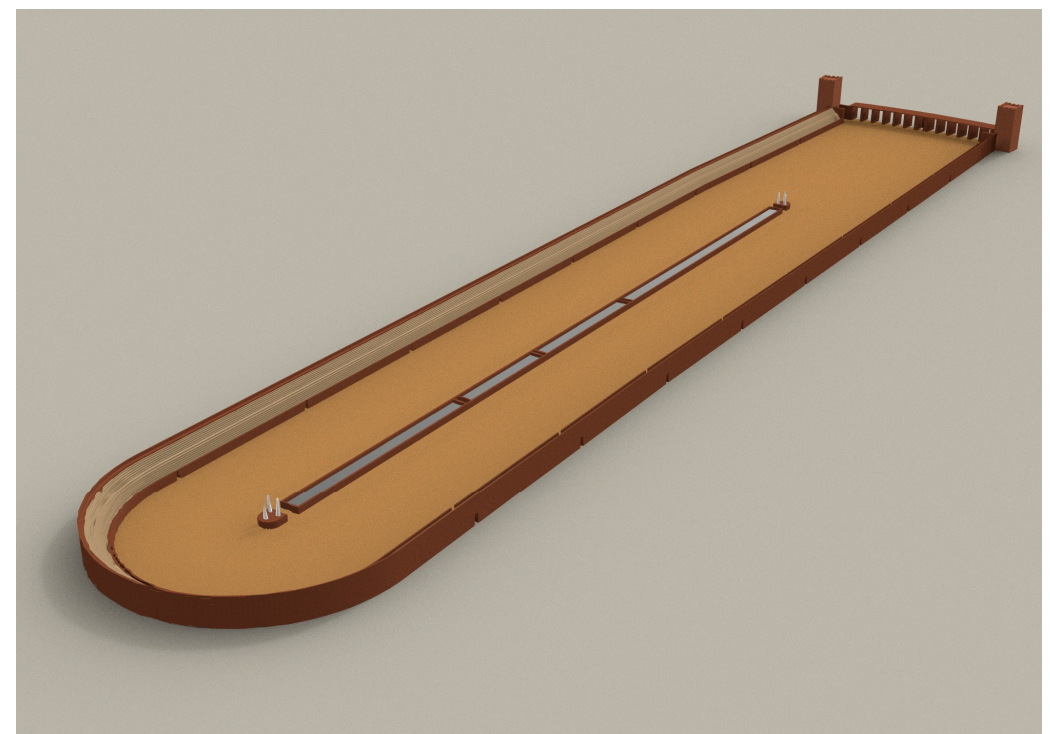

(a)

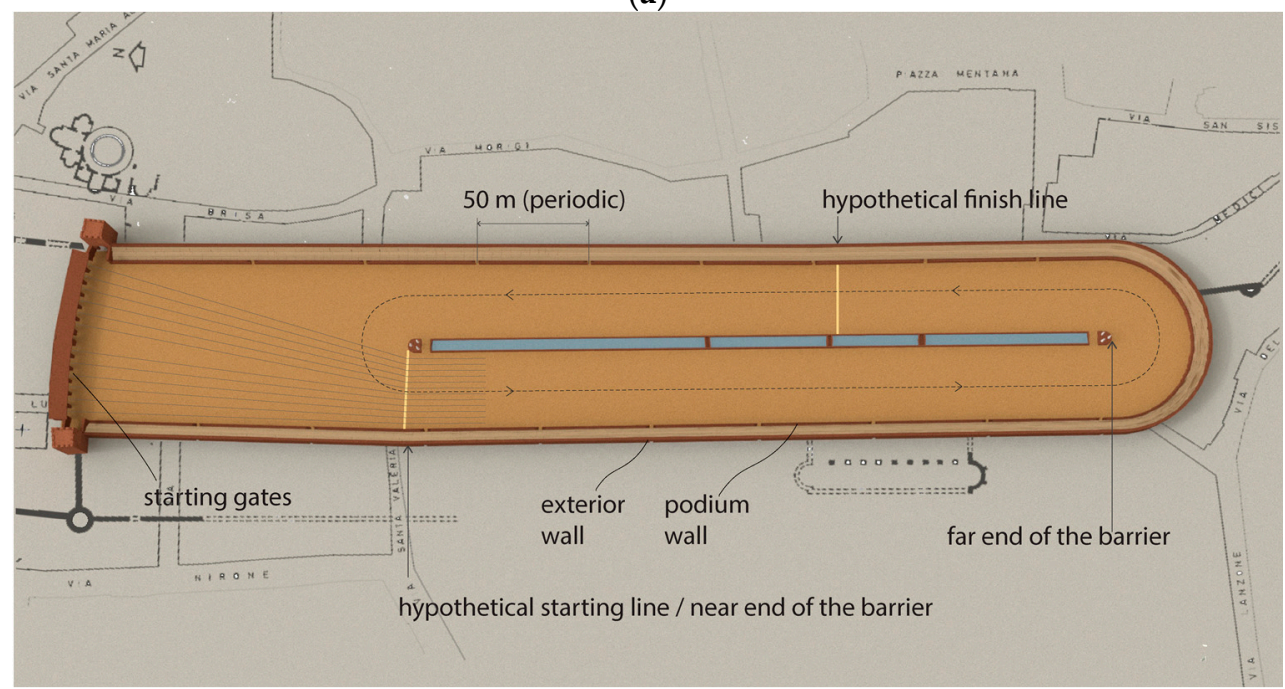

(b)

Figure 12. The reconstruction of the circus: (a) prospective view; (b) a plan view overlapped to the city map from which it is possible to see the change of direction of the exterior walls in correspondence with the starting line, a technical expedient to permit all the chariots to run the same length before arriving at the starting line.

From the surveys, on the other hand, it was possible to exactly place the two towers, one of the carceres, and one related to the city walls, and it is expected to confirm or update the map with the future surveys. Other important information was gathered during the survey in Via Vigna shown in Figures 4 and 5, where the discovery of a few remnants of the internal wall of the Circus allowed us to set the exact distance between the two walls, and consequently, as noted previously, the slope of the seats shown in Figure 6. One part of the main data that has yet to be verified, is the divergence of the walls of the circus in the western part, made to provide the same starting line for all the chariots. As shown in the lower left part of Figure 12b, as of now, the reconstruction has been carried out 
with the Mirabella Roberti hypothesis as its basis, based in turn on comparisons with other circuses. This hypothesis is under verification, with specific 3D surveys in the basements of private houses containing a few remains of these structures.

Most of the reconstruction, unfortunately, was made by comparing similar structures still visible, such as the circus of Maxentius, the Circus Maximus and the Flavian Amphitheatre in Rome. No traces were found of the spina, the central line whose function was to divide the track, and on which, there was the lap-counter. In the Circus of Milan, most probably, it was marked by marble eggs, one of which was lowered for each lap finished by the first chariot. This hypothesis is based on the discovery of one of these eggs during the excavations in the area of the circus.

For this reconstruction, in addition to the discussion and hypothesis with the archaeologists, and the comparison with similar structures built in the Roman period, the archival and bibliographic documentation is used to better identify the proper structure of the building, especially the drawings by Corni (Figure 13). Although these drawings are very hypothetical, and sometimes contain reconstructive errors, they can be used as a starting point to figure out how the elevated structures might have looked like.

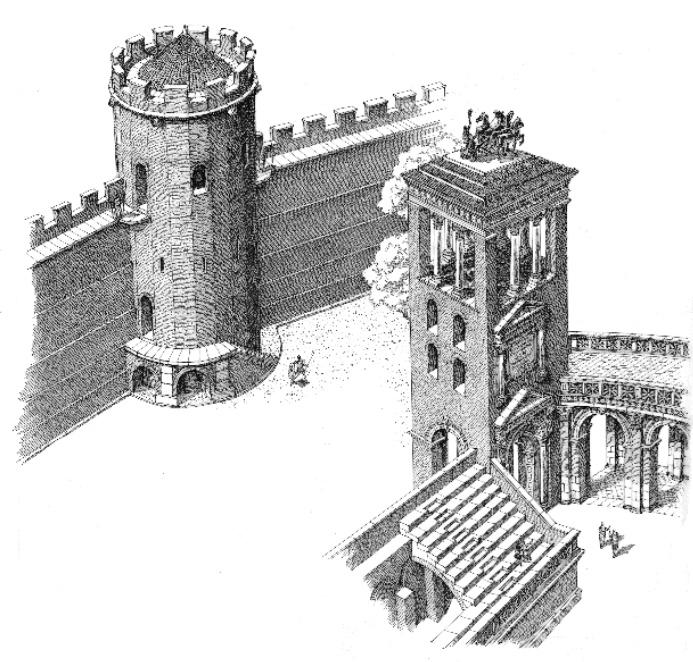

(a)

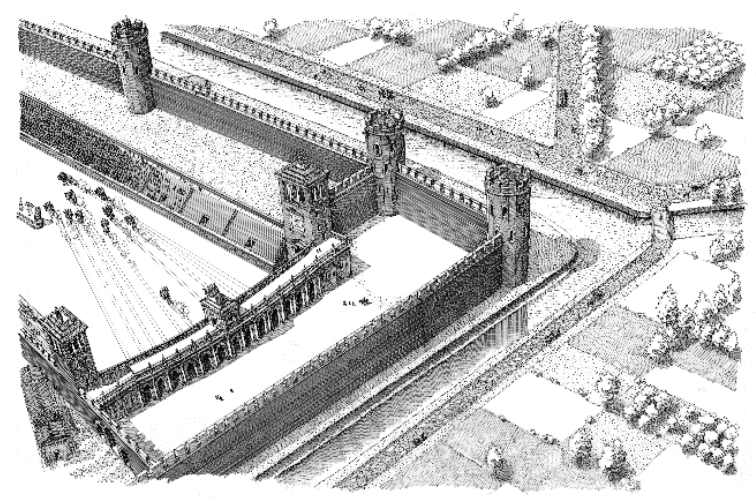

(c)

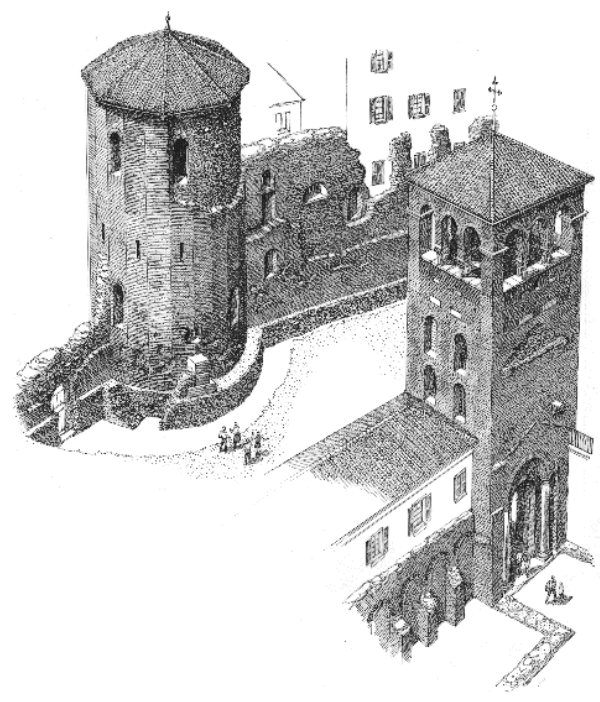

(b)

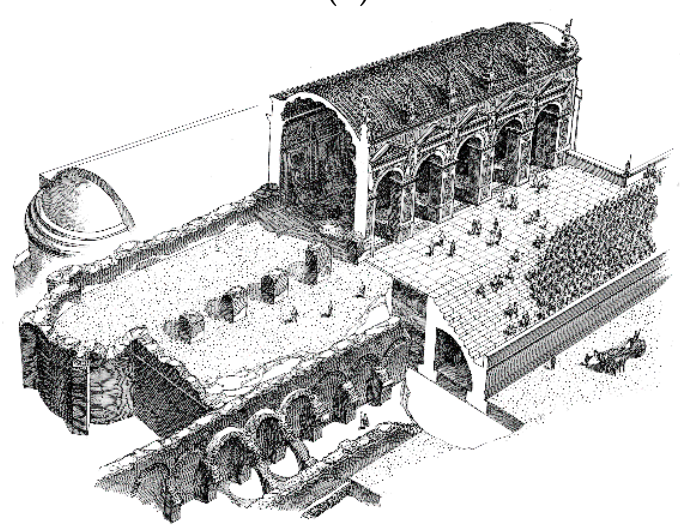

(d)

Figure 13. Drawing by Corni (courtesy of the Directorate of the Archaeological Museum) about the reconstruction of some parts of the Circus: (a) the tower of the city walls facing the tower of the carceres as they were during the late roman time; (b) as they look now inside the garden of the archaeological museum; (c) the view from the starting point of the races; (d) the hypothesis of the dais where the emperor and his entourage watched the races. 
Finally, the 3D reconstruction of the circus was imported in a GIS platform and overlapped on the 3D model of the corresponding portion of the city (Figure 14), georeferenced with markers on the same coordinate system of the GIS map. On the continuation of the project, the georeferencing of the structures of the Circus and the city plan will be improved with other topographical and 3D surveys. Such work involves the laser scanning of each remain in the basements of private apartments. The laser survey covers both the underground structure (where the GPS cannot work) and the external part of the building, in order to catch the GPS signal. On some natural point a differential GPS is used for gathering precise georeferenced coordinates of at least three points of the scanned structure. The same points are then extracted by the laser scanned model, and through the two sets of coordinates, the roto-translation matrix from the laser scanner coordinate system to the georeferenced coordinate system is calculated, thanks to a procedure based on the quaternion method [39].

This alignment of the ancient structure with the existing urban fabric is important for several reasons: (i) the city can have a better perception of a lost monument, probably the second most important after the imperial palace, during the last years of the western Roman Empire; (ii) it will help to define, in an accurate way, the position of the remains, and to identify a buffer zone in which it might be possible to find them; (iii) it will help to better organize the urban intervention in the area; (iv) some elements of the structure, still missing, can be placed in a precise way, helping to identify the probable areas in which to intervene with excavations.

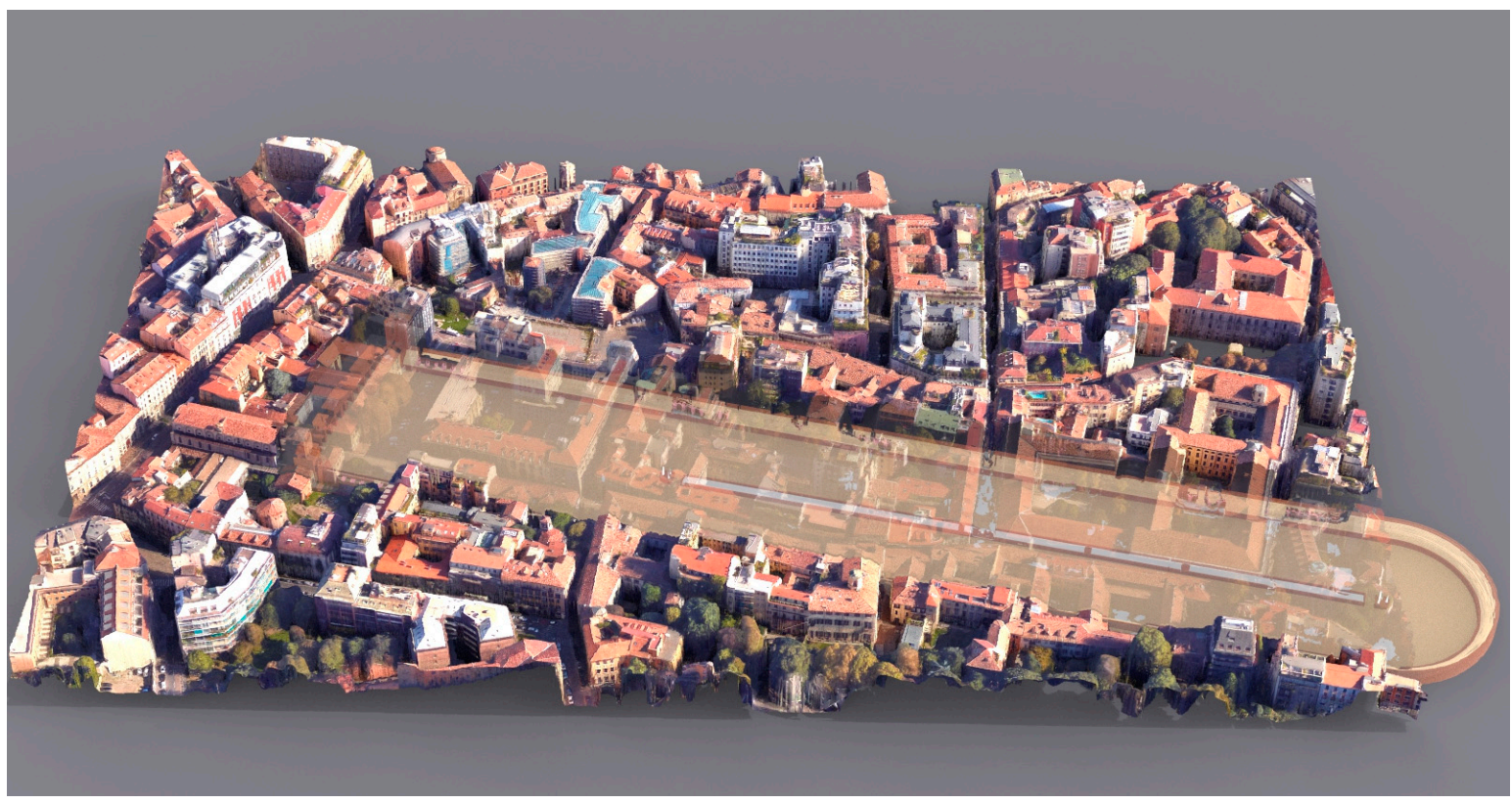

Figure 14. The overlapping of the georeferenced reconstruction of the circus on $3 \mathrm{D}$ map of the related area.

\section{Discussion and Conclusions}

The purpose of the digital reconstruction of the ancient Roman circus of Milan was to give a visual representation to a structure whose formal details, although studied by several authors in the past 70 years, was not very clear.

This large structure of the past had a huge impact on the city at the time of its construction, involving the change of the course of a river, and the complete redefinition of the southern part of the city of Milan.

The digital reconstruction of such a monument was particularly complex, due to the presence of the few remains, in the underground of an active and lively city, mostly in the basements of private houses. This raised the typical problems of archaeological studies in urban areas, such as: (i) the need to 
agree to a proper survey action with the national authority for the protection of archaeological heritage (Archaeological Superintendence of Milan), adding a heavy load of bureaucratic activity to the typical research work; (ii) the technical issue of having most of the 3D surveys referred to the basements of private houses, imposed to generate laser scanned 3D models of larger areas in order to include in the same model both the underground and parts of the exteriors. In this way, it has been possible to relocate in space each small portion of the circus remains, with a GPS, thus obtaining important clues related to the orientation of the structure in space. Such information allowed us to reconstruct the position of some elements of the circus, never studied before; and (iii) the digitally reconstructed structure of the circus will allow us to communicate to the citizens of Milan, and to visitors in general, the impact on the city and on its future development of such a gigantic historical artefact.

Thanks to geoscience, it was possible to identify and place in space the different portions of the monument, most of them not visible because they are hidden in basements or gardens of private houses. This will be a big step in the study of the Roman city of Milan, helping archaeologists to better define the structure. The work done with the Superintendence regarding the different hypothesis of the reconstruction is truly useful even for scholars, because it forces them to analyze all the documentation. On the other hand, the possibility of seeing the structure in 3D helps them to have a clear idea of the monument, and so to identify the best way to reconstruct the building.

Finally, this work will make it possible for anyone who is interested to understand and appreciate a lost, important monument of their city, because most of the people do not even know of the existence of the circus. Having the perception of the structure among the modern streets and buildings is the best way to help non-experts to understand the dimensions and the importance of the monument, while the tridimensional reconstruction will help people to gain a better comprehension of the building itself.

Acknowledgments: The authors wish to acknowledge the support of the Joint Programming Initiative on Cultural Heritage (JPICH) for funding the project Cultural Heritage through Time (CHT2), with the contribution of MiBACT, MIUR and the European Commission. The author would like to thank Anna Maria Fedeli from the Archaeological Superintendence of Milan, Donatella Caporusso and Anna Provenzali, from the Archaeological Museum of Milan for their precious cooperation in providing documentation on the area, and also for their help with the archival research. Finally, a special thank you goes to the archaeologist Simona Morandi for some useful discussions and for letting us access unpublished surveys related to the square tower that were useful for supporting the reconstruction hypotheses reported here.

Author Contributions: Gabriele Guidi is the coordinator of the project and of the surveys; Laura Loredana Micoli collected and organized the bibliographic and archival data, followed the relation with the Superintendence and performed the surveys; Sara Gonizzi Barsanti designed and created the GIS and the geodatabase, performed the surveys and participated to the collection of bibliographic data; Umair Malik performed the surveys and the 3D reconstruction of the circus. Gabriele Guidi and Sara Gonizzi Barsanti wrote the paper.

Conflicts of Interest: The authors declare no conflict of interest.

\section{References}

1. Russo, M.; Guidi, G.; Russo, M. Reality-Based and Reconstructive models: Digital Media for Cultural Heritage Valorization. SCIRES-IT 2011, 1, 71-86. [CrossRef]

2. Gruen, A. Reality-based generation of virtual environments for digital earth. Int. J. Digit. Earth 2008, 1, 88-106. [CrossRef]

3. Remondino, F.; Rizzi, A. Reality-based 3D documentation of natural and cultural heritage sites-techniques, problems, and examples. Appl. Geomat. 2010, 2, 85-100. [CrossRef]

4. De Luca, L.; Veron, P.; Florenzano, M. Reverse engineering of architectural buildings based on a hybrid modeling approach. Comput. Graph. 2006, 30, 160-176. [CrossRef]

5. Sullivan, E. Potential pasts: Taking a humanistic approach to computer visualization of ancient landscapes. Bull. Inst. Class. Stud. 2016, 59. [CrossRef]

6. Reilly, P. Towards a virtual archaeology. In British Archaeological Reports International Series; Archeopress: Oxford, UK, 1991; Volume 565, pp. 133-139.

7. Dam, A.V.; Forsberg, A.S.; Laidlaw, D.H.; LaViola, J.J.J.; Simpson, R.M. Immersive VR for scientific visualization: A progress report. IEEE Comput. Graph. Appl. 2000, 20, 26-52. [CrossRef] 
8. Barcelò, J.A.; Forte, M.; Sanders, D.H. Virtual Reality in Archaeology; British Archaeological Reports; International Series; Archeopress: Oxford, UK, 2000; ISBN 978-1-84171-047-1.

9. Beyond Illustration: 2D AND 3D Digital Technologies as Tools for Discovery in Archaeology; Frischer, B.; Dakouri-Hild, A. (Eds.); Archaeopress: Oxford, UK, 2008; ISBN 978-1-4073-0292-8.

10. Smith, J.S.; Rusinkiewicz, S.M.; Alberti, S.; Chen, J.; Coronado, M.; Disco, G.; Georgiou, A.; Pico, T.; Touloumes, G.; Triolo, G. Modeling the Past Online: Interactive Visualisation of Uncertainty and Phasing; Springer: Cham, Switzerland, 2014; Volume 8740.

11. Happa, J.; Mudge, M.; Debattista, K.; Artusi, A.; Gonçalves, A.; Chalmers, A. Illuminating the past: State of the art. Virtual Real. 2010, 14, 155-182. [CrossRef]

12. The London Charter for the Computer-Based Visualisation of Cultural Heritage (Version 2.1, February 2009); Ashgate Publishing Ltd.: Surrey, UK, 2012; ISBN 978-0-7546-7583-9.

13. Frischer, B.; Abernathy, D.; Guidi, G.; Myers, J.; Thibodeau, C.; Salvemini, A.; Müller, P.; Hofstee, P.; Minor, B. Rome reborn. In ACM SIGGRAPH 2008; ACM Press: Los Angeles, CA, USA, 2008.

14. Stumpfel, J.; Tchou, C.; Yun, N.; Martinez, P.; Hawkins, T.; Jones, A.; Emerson, B.; Debevec, P. Digital Reunification of the Parthenon and its Sculptures. In Proceedings of the 4th International Conference on Virtual Reality, Archaeology and Intelligent Cultural Heritage, Brighton, UK, 5-7 November 2003; pp. 41-50.

15. Gabellone, F. Ancient contexts and virtual reality: From reconstructive study to the construction of knowledge models. J. Cult. Herit. 2009, 10, e112-e117. [CrossRef]

16. Allen, P.; Feiner, S.; Troccoli, A.; Benko, H.; Ishak, E.; Smith, B. Seeing into the past: Creating a 3D modeling pipeline for archaeological visualization. In Proceedings of the 2nd International Symposium on 3D Data Processing, Visualization and Transmission (3DPVT 2004), Thessaloniki, Greece, 9 September 2004; pp. 751-758.

17. Welham, K.; Shaw, L.; Dover, M.; Manley, H.; Pearson, M.P.; Pollard, J.; Richards, C.; Thomas, J.; Tilley, C. Google under-the-earth: Seeing Beneath Stonehenge using Google Earth-A tool for public engagement and the dissemination of archaeological data. Internet Archaeol. 2015. [CrossRef]

18. Buna, Z.; Popescu, D.; Comes, R.; Badiu, I.; Mateescu, R. Engineering CAD tools in digital archaeology. Mediterr. Archaeol. Archaeom. 2014, 14, 83-91.

19. Gonizzi Barsanti, S.; Guidi, G. A Geometric Processing Workflow for Transforming Reality-Based 3D Models in Volumetric Meshes Suitable for Fea. In ISPRS-International Archives of the Photogrammetry, Remote Sensing and Spatial Information Sciences; COPERNICUS: Nafplio, Greece, 2017; Volume XLII-2/W3, pp. 331-338.

20. Gutierrez, D.; Seron, F.J.; Magallon, J.A.; Sobreviela, E.J.; Latorre, P. Archaeological and cultural heritage: Bringing life to an unearthed Muslim suburb in an immersive environment. J. Cult. Herit. 2004, 5, 63-74. [CrossRef]

21. Callieri, M.; Debevec, P.; Pair, J.; Scopigno, R. A realtime immersive application with realistic lighting: The Parthenon. Comput. Graph. 2006, 30, 368-376. [CrossRef]

22. Laycock, R.G.; Drinkwater, D.; Day, A.M. Exploring cultural heritage sites through space and time. J. Comput. Cult. Herit. 2008, 1, 1-15. [CrossRef]

23. Guidi, G.; Russo, M. Diachronic representation of ancient buildings: Studies on the "San Giovanni in Conca" Basilica in Milan. Disegnare Con 2009, 2, 69-80.

24. Micoli, L.L.; Guidi, G.; Angheleddu, D.; Russo, M. A multidisciplinary approach to 3D survey and reconstruction of historical buildings. In 2013 Digital Heritage International Congress (DigitalHeritage); IEEE: New York, NY, USA, 2013; pp. 241-248. Available online: http:/ / ieeexplore.ieee.org/abstract/document/ 6744760/ (accessed on 20 September 2017).

25. Garcia Puchol, O.; McClure, S.B.; Blasco Senabre, J.; Cotino Villa, F.; Porcelli, V. Increasing contextual information by merging existing archaeological data with state of the art laser scanning in the prehistoric funerary deposit of Pastora Cave, Eastern Spain. J. Archaeol. Sci. 2013, 40, 1593-1601. [CrossRef]

26. Guidi, G.; Russo, M.; Angheleddu, D. 3D Survey and Virtual Reconstruction of archeological sites. Digit. Appl. Archaeol. Cult. Herit. 2014, 1, 55-69. [CrossRef] 
27. Rodríguez-Gonzálvez, P.; Muñoz-Nieto, A.L.; Del Pozo, S.; Sanchez-Aparicio, L.J.; Gonzalez-Aguilera, D.; Micoli, L.L.; Gonizzi Barsanti, S.; Guidi, G.; Mills, J.; Fieber, K.; et al. 4D Reconstruction and visualization of Cultural Heritage: Analyzing our legacy through time. Int. Arch. Photogramm. Remote Sens. Spat. Inf. Sci. 2017, XLII-2/W3, 609-616. [CrossRef]

28. De Capitani d'Arzago, A. Il Circo romAno; Ricerche della Commissione per la forma urbis Mediolani/Istituto di studi romani, Sezione lombarda; De Capitani d'Arzago, A., Calderini, A., Eds.; Ceschina: Milano, Italy, 1939.

29. Mirabella Roberti, M. Milano Romana; Rusconi: Sant'Arcangelo di Romagna, Italy, 1984; ISBN 88-18-33964-8.

30. Blockley, P.; Caporusso, D. Area del Monastero Maggiore in epoca romana/[testi di Paul Blockley ... et al.]; Civico Museo Archeologico: Milano, Italy, 2013; ISBN 978-88-97568-08-7.

31. Caporusso, D.; Donati, M.T.; Masseroli, S.; Tibietti, T. Immagini di Mediolanum-Archeologia e storia di Milano dal V secolo a.C. al V secolo d.C.; Civico Museo Archeologico di Milano: Milano, Italy, 2014; ISBN 978-88-97568-00-1.

32. Colombo, A. Milano preromana, romana e longobarda; Meravigli: Milano, Italy, 1994; ISBN 88-7955-069-1.

33. L'area archeologica del Monastero Maggiore di Milano: una nuova lettura alla luce delle recenti indagini; Pagani, C.; Blockley, P.; Cecchini, N. (Eds.); Quaderni del Civico museo archeologico e del Civico gabinetto numismatico di Milano: Milano, Italy, 2012.

34. Sena Chiesa, G. Milano capitale dell'impero romano: 286-402 d.C.; Silvana Editoriale: Milano, Italy, 1990; ISBN 978-88-366-0276-6.

35. Humphrey, J.H. Roman Circuses: Arenas for Chariot Racing; University of California Press: Berkeley/Los Angeles, CA, USA, 1986; ISBN 978-0-520-04921-5.

36. Fedeli, A. Milano Archeologia. I luoghi della Milano antica; Fondazione Cariplo: Milano, Italy, 2015; ISBN 978-88-86752-69-5.

37. Capponi, C.; Ambrosini, A. San Maurizio al Monastero Maggiore in Milano: Guida Storico Artistica; Silvana Editoriale: Cinisello Balsamo, Milano, Italy, 1998; ISBN 88-8215-095-X.

38. Guidi, G.; Russo, M. Diachronic 3D reconstruction for lost Cultural Heritage. Int. Arch. Photogramm. Remote Sens. Spat. Inf. Sci. 2011, XXXVIII-5/W16, 371-376. [CrossRef]

39. Horn, B.K.P. Closed-form solution of absolute orientation using unit quaternions. J. Opt. Soc. Am. A 1987, 4, 629. [CrossRef]

(C) 2017 by the authors. Licensee MDPI, Basel, Switzerland. This article is an open access article distributed under the terms and conditions of the Creative Commons Attribution (CC BY) license (http://creativecommons.org/licenses/by/4.0/). 